\title{
Comparison of Regarding Students' Learning Motivation by Gender During the Online Learning
}

\author{
Nimas Putri Dewi Puspitaningrum ${ }^{1, *}$ Anti Kolonial Prodjosantoso ${ }^{2,}$ Delyanti
}

\author{
Azzumarito Pulungan ${ }^{3}$ \\ ${ }^{1}$ Master of Chemistry Education, Faculty of Mathematic and Natural Sciences, Universitas Negeri Yogyakarta, \\ Yogyakarta, Indonesia \\ ${ }^{2}$ Department of Chemistry Education, Faculty of Mathematic and Natural Sciences, Universitas Negeri Yogyakarta, \\ Yogyakarta, Indonesia \\ ${ }^{3}$ Universitas Prima Indonesia, Medan, Sumatera Utara, Indonesia \\ *Corresponding author. Email: nimasputri.2019@student.uny.ac.id
}

\begin{abstract}
This study's objectives were to investigate and analyze comparisons of students' learning motivation during online learning based on gender. This quantitative study used a survey design. The subject study consisted of 331 students in the high school selected from science majors using the convenience sampling technique. The Instrument was adopted by The Motivated Strategies Learning Questionnaire (MSLQ), which consisted of five aspects (self-efficacy, intrinsic value, test anxiety, strategy use, self-regulation). The Instrument was tested valid and reliable to use. Data analyzed was used descriptive statistics and Mann Whitney test. These findings that the female student's mean score of learning motivation is higher than the male student's mean score. Based on the Mann-Whitney test results, there is a significant difference in the mean score of learning motivation between male and female students. Finally, we suggest further research on gender differences in learning motivation using a larger population and more extensive research about investigating the relationship or influence of students' learning motivation toward gender.
\end{abstract}

Keywords: Learning motivation, Online learning, Survey, Gender

\section{INTRODUCTION}

Education is the core of a valuable asset for the future and increases the superior quality of life. In the world of education, a person can develop their abilities and have the opportunity to explore various things related to skills, knowledge, use of technology to planting moral values so that they are embedded in the individual [1]. Along with the development of 21stcentury technology, learning which has initially been from face-to-face learning in class, then developed into blended learning until now, is required to utilize online learning fully [2]. It is also happening now when we are in the industrial era 4.0. Overall, using technology daily occurs in all aspects, both from an economic and social perspective, including world education aspects. [3].

In recent years, education has undergone various changes in line with increasingly sophisticated and rapid technology. Because of that, it demands the world of education so that it is not left behind with the times and is invincible with technological changes. In the current era, technology has become a student need in the learning process, so students must be able to use technology proficiently [4]. Initially, the technology was only used as a learning support facility. However, it is now the main thing needed during this pandemic and the primary means of learning online. Currently, learning can be done anytime and anywhere without being bound by time and space.

The current COVID-19 pandemic has resulted in sudden and very rapid changes, including in the world of education. The spread of the COVID-19 pandemic worldwide has caused face-to-face learning in schools and universities to be suspended temporarily. Teachers have made various attempts to replace face-to-face learning that cannot be held with online learning. Teachers and students, including students majoring in science, must through tough challenges, experienced this situation. [5] Almost all countries that affect the covid-19 pandemic, include our Indonesia, were forced to change face-to-face learning to online learning in an uncertain time. It needs adaptation in carrying out the online teaching and learning process, especially the teacher needs to apply alternative and effective learning 
methods and appropriate assessments for students. Even teachers are not yet ready for online teaching. but they must ensure students can continue to learn with find learning approaches and strategies that relevant to applicable in times of pandemic like this [6].

Online learning is one of today's alternative modern methods that increase students' efficiency and learn more responsibilities. Students become better able to discover, analyze, construct, and acquire high-level learning skills. Online learning becomes a form of delivery of student-centered learning, a learning environment that can be done anytime with various advanced technology sources [7]. Changes in e-learning will impact students, such as student time on assignments and several disturbances that hinder them from doing tasks, about learning motivation, and encouragement to achieve their success and supporting facilities. The circumstances of the students greatly influence online learning. In online learning, students are required to have the ability to learn independently [8].

Several studies have reported motivation to be one of the influencing factors in creating self-regulating learners. During this transition to online learning, many students learn that they must increase their dependence on their learning. Many students can do it. However, other students experience a loss of motivation when they do not have their teachers and classmates to encourage them in the learning process. Various factors influence motivation, including the participation of classmates and external sources. Motivation to learn and interest in learning must be fostered in online education because without it, and students will feel heavy and depressed in online learning [8].

Someone can be enthusiastic and diligent in doing something because of encouragement and motivation. Motivation can be defined as a person's mental strength that can encourage and trigger activity to achieve specific goals. Motivation can occur naturally by itself (intrinsic motivation) or by external factors (intrinsic motivation). Motivation is needed in online learning, where students with motivation are expected to be enthusiastic and active in learning even though online learning in a pandemic like this [9].

Learning motivation, especially in science learning, an essential factor in independent learning and student academic achievement over a long time [10]. Appropriate and effective learning increased students' motivation to learn, which was also included in online learning [11].

Learning motivation can measure with the instrument of the Motivated Strategies for Learning
Questionnaire (MSLQ). The MSLQ was developed using a social-cognitive view of motivation and learning strategies [12]. The MSLQ consists of a motivation section and a learning strategies section. Analysis of the motivation section revealed three distinct motivational factors: self-efficacy, intrinsic value, and test anxiety. Then a learning strategies section consisted is cognitive strategy use and self-regulation. The instrument MSLQ used to score on a 7-point Likert-type scale, from scale 1 -7 (not at all true to very true) for each individual [13].

This study aims to investigate and analyze students' learning motivation based on gender during the online learning process. The study's questions were: (1) Is there a different significance of male and female students' learning motivation during the online learning process? (2) which has higher learning motivation in online learning, male students or female students?

\section{METHOD}

\subsection{Participants}

The participants of this research consisted of 331 students from senior high school who science majors. The technique sampling was used convenience sampling.

\subsection{Design and Instruments}

This quantitative study used a survey design. This study aims investigate and analyze different students learning motivations based on gender in the online learning process. Data collected was used online questionnaires. It is distributed in the link form of a google form where students can fill out the questionnaire.

Online questionnaire were distributed to high school students majoring in science. Students got to inform that the questionnaire data's confidentiality was guaranteed before filling out the online questionnaire. Students fill out the questionnaire voluntarily without coercion. The accuracy of data sampling is ensured with there a write is only intended for high school students majoring in science in the questionnaire after the data was collected, and then selected, re-examined who are senior high school students majors science.

Learning motivation can measure with the instrument the Motivated Strategies for Learning Questionnaire (MSLQ). The instrument in this study was the adoption of MSLQ. The MSLQ consists of a motivation section and a learning strategies section. The MSLQ in this study used five categories (self-efficacy, intrinsic value, test anxiety, strategy use, self-regulation) 
with 4-point Likert scale answer choices ranging from (4) strongly agree, (3) agree, (2) disagree, (1) strongly disagree [12].

\subsection{Validity and Reliability}

Prior to the instrument used to collect data, It is tested to see the level of validity and reliability. The empirical validity was tested for 30 students who become respondents in one senior high school in Yogyakarta. The results of the validity test were calculated using the Pearson correlation coefficient between items. Valid if the coefficient significant less than $0.05(\alpha<0.05)$. Based on the result analysis is nine items statement valid from twelve items. The Cronbach alpha method is used for reliability testing. The $\alpha$ coefficient is 0.807 , which means that the reliability is good, so it is accepted for used this research [14]. Table 1 shows the final version of the MSLQ in the study, which consists of nine items.

Table 1. Final version of instrument the MSLQ

\begin{tabular}{|c|c|c|}
\hline No. & Categories & Statement \\
\hline 1. & $\begin{array}{l}\text { Self- } \\
\text { Efficacy }\end{array}$ & $\begin{array}{l}\text { I believe I can do a very good job } \\
\text { on the problems and assignments } \\
\text { given in class }\end{array}$ \\
\hline \multirow[t]{2}{*}{2.} & \multirow[t]{2}{*}{$\begin{array}{l}\text { Instrinsic } \\
\text { Value }\end{array}$} & $\begin{array}{l}\text { I prefer challenging assignments } \\
\text { so that I can learn new things }\end{array}$ \\
\hline & & $\begin{array}{l}\text { When I do less than my exams, I } \\
\text { try to learn from my mistakes }\end{array}$ \\
\hline 3. & $\begin{array}{l}\text { Test } \\
\text { Anxiety }\end{array}$ & I am very worried about the exam \\
\hline \multirow[t]{2}{*}{4.} & \multirow[t]{2}{*}{$\begin{array}{l}\text { Cognitive } \\
\text { Strategy } \\
\text { Use }\end{array}$} & $\begin{array}{l}\text { When studying, I copy my notes } \\
\text { over to help me remember } \\
\text { material }\end{array}$ \\
\hline & & $\begin{array}{l}\text { When I study, I put important } \\
\text { ideas into my own words. }\end{array}$ \\
\hline \multirow[t]{3}{*}{5.} & \multirow[t]{3}{*}{$\begin{array}{l}\text { Self- } \\
\text { Regulation }\end{array}$} & $\begin{array}{l}\text { Even when study materials are } \\
\text { dull and uninteresting, I keep } \\
\text { working until I finish }\end{array}$ \\
\hline & & $\begin{array}{l}\text { Before I begin studying, } \\
\text { I think about the things I will need } \\
\text { to do to learn }\end{array}$ \\
\hline & & $\begin{array}{l}\text { I work hard to get a good grade } \\
\text { even when I don't like a material }\end{array}$ \\
\hline
\end{tabular}

\subsection{Data Analysis}

Descriptive statistics and The Mann-Whitney test are data analyses in this study. All statistical analyses were performed using SPSS (Statistical Package for the Social Sciences) software version 25.0. The descriptive statistics analyzed were the number of samples, minimum and maximum scores, means, and standard deviations.

Prior to the Mann-Whitney test, the normality and homogeneity tests were carried out. The Mann-Whitney nonparametric test is another alternative to the independent sample T-test. Typically, this test was used to analyze data if the data is considered not normally distributed. The Mann-Whitney test was conducted to examine whether there was a difference significant the male and female students' learning motivation during the online learning process.

\section{RESULTS AND DISCUSSION}

This study aims investigate and analyze different students learning motivations based on gender in the online learning process. Based on the results of the questionnaire that had been distributed, students who filled out the questionnaire were 331 senior high school students majoring in science, where the male students were $91(27.4 \%)$. The female students were 240 $(72.7 \%)$. The majority of the participants were female students.

Prior to the Mann-Whitney test, analysis is carried out, the prerequisite test is carried out, namely the normality test and the homogeneity test to determine whether the result data is normally distributed or not, and the result data is homogeneous or not. The output of normality test analysis presented in Table 2.

Table 2 presented the normality test's output; there are two significant values: Kolmogorov-Smirnov and Shapiro-Wilk. 
Table 2. The output of normality test analysis

\begin{tabular}{|l|l|r|r|r|r|r|r|}
\hline \multirow{2}{*}{} & \multirow{2}{*}{} & \multirow{2}{*}{ Gender } & \multicolumn{3}{|c|}{ Kolmogorov-Smirnov } & \multicolumn{4}{c|}{ Shapiro-Wilk } \\
\cline { 3 - 8 } & & Statistic & df & \multicolumn{1}{c|}{ Sig. } & \multicolumn{1}{c|}{ Statistic } & \multicolumn{1}{c|}{ df } & \multicolumn{1}{c|}{ Sig. } \\
\hline \multirow{2}{*}{$\begin{array}{l}\text { Learning } \\
\text { motivation }\end{array}$} & Male & 0.110 & 91 & 0.008 & 0.933 & 91 & .000 \\
\cline { 2 - 8 } & Female & 0.080 & 240 & 0.001 & 0.969 & 240 & .000 \\
\hline
\end{tabular}

${ }^{\star}$ This is a lower bound of the true significance

a. Lilliefors Significance Correction

This study uses the Kolmogorov-Smirnov consideration in the normality test because the sample is more than 200 participants. The data results are normally distributed (symmetrical) if the significant (sig) value is greater than 0.05 [15]. Based on the hypothesis showed that the scores of male and female students learning motivation are both not normally distributed, where the sig value for the male students is $(0.008<0.05)$ and the sig value for female students $(0.001<0.05)$. Levene's test of equality, the variance shows a sig value of 0.599 , and then the same variant is assumed to exist ( $\operatorname{sig} 0.586>0.05$ ). So, the data result is homogeneous.

After the normality test, so the mean score was analyzed with the Mann-Whitney test. Mann-Whitney test analysis is a nonparametric statistical method used as an alternative to the Independent Sample T-test if the data have been known as not normally distributed. Thus, the Mann-Whitney nonparametric test can be used to determine whether there is a significant difference in the mean score of learning motivation between the male and female students. The results of the Mann-Whitney test are shown in Table 3.

Table 3. Mann Whitney U test results

\begin{tabular}{|l|c|}
\hline \multicolumn{1}{|c|}{ Test } & Sig. \\
\hline Man-Whitney U test & 0.002 \\
\hline \multicolumn{2}{|l|}{ The signifincance level is 0.05} \\
\hline
\end{tabular}

The value (2-tailed) in Table 3 presents a value of 0.002 . The sig (2-tailed) value for the variance equation is assumed to be found to be $0.002<0.05$. If the significance $(\alpha)$ is less than 0.05 , then Ho is rejected. Thus, there is a significant difference in students' learning motivation of males and females in online learning.

Other studies support the results of this study in which students' motivation to learn science could be influenced by the interaction between the sexes, the results of the analysis are similar; there is a significant difference between the learning motivation of male and female students because motivation can indeed be influenced by the gender of the student [16].

Furthermore, a descriptive statistical analysis needs to be done to determine which mean score of learning motivation is higher among male and female students. Table 4 presents a description of the data analysis of learning motivation scores based on gender

Table 4. Description of data analysis for learning motivation of female and male students

\begin{tabular}{|c|c|c|c|c|c|}
\hline Gender & $\mathbf{N}$ & $\min$ & $\max$ & Mean & $\begin{array}{c}\text { Standard } \\
\text { Deviation }\end{array}$ \\
\hline Male & 91 & 9 & 36 & 28.34 & 4.17 \\
\hline Female & 240 & 18 & 36 & 29.79 & 3.59 \\
\hline
\end{tabular}

We can see on Table 4 that the mean score of female students' learning motivation in online learning is higher than that of male students. Then, there is a low standard deviation of male students with a value of 4.17 and 3.59 for female students, where the difference in standard deviation scores is small between male and female students.

There are research results concerning the influence of gender, showing that the gender effect is statistically significant for motivation chemistry /science learning with female students than for male students [17]. It showed that the learning motivation of female students was higher than that of male students. The overall score for the learning motivation of female students is higher [18]

Many studies have been conducted showing that students who was motivated to learn will influence their learning This is supported in other studies, that learning motivation was effected on student achievement was significant [10]. Research carried out relating to the 
measurement of motivation in learning can test the relationship between the components of motivation and other factors such as personality, academic achievement, or intelligence [19].

Despite the limitations, the findings of this study have implications regarding that there is a significant difference in student learning motivation by gender during online learning. Futhure reseach, it is also necessary to examine the relationship between learning motivation and gender, majors, grade level, academic achievment and other demographics.

\section{CONCLUSION}

The conclusion in this study that there is a significant difference in students' learning motivation between males and females during online learning. The mean score of learning motivation that female students higher than the mean score of male students.

\section{ACKNOWLEDGMENTS}

Researcher want to thank to all participants who have helped researcher in completing this research.

\section{REFERENCES}

[1] D.P. Diwanti, Suryanto, S. Iswati, T.S. Agustina, H.B. Notobroto, The effect of learning motivation and social support on learning achievement of the students in aisyiyah female orphanage serangan yogyakarta, Proceedings of the 4th International Conference on Sustainable Innovation 2020-Social, Humanity and Education (ICoSIHESS), Advances in Social Science, Education, and Humanities Research, vol. 518, Atlantis Press, Amsterdam, The Netherlands, 2021, pp. 42-48. DOI: https://doi.org/10.2991/assehr.k.210120.103

[2] B.M. Wright, Blended learning: student perception of face-to-face and online EFL lessons, Indonesian Journal of Applied Linguistics 7 (2017) 64-71. DOI: $\underline{\text { https://doi.org/10.17509/ijal.v7i1.6859 }}$

[3] E.S. Harida, Jufrizal, H. Syarif, Ratmanida, A study of students' perceptions of online learning in blended learning and flipped classroom, Proceedings of $2^{\text {nd }}$ International Conference Inovation in Education (ICoIE), Advances in Social Science, Education, and Humanities Research, vol. 504, Atlantis Press, Amsterdam, The Netherlands, 2020, pp. 263-268. DOI: https://doi.org/10.2991/assehr.k.201209.231.

[4] A.G. Shatri, Advantages and disadvantages of using information technology in learning process of students, Journal Turkish Science Education 17 (2020) 420-428.

[5] W.K. Chiu, Implications for use of powerpoint classroom response systems, teams, and whiteboard to enhance online teaching of chemistry subject in community college, in: Journal of Chemical Education 97 (2020) 3135-3159. DOI: https://doi.org/10.1021/acs.jchemed.0c00830.

[6] J.W.J. Ang, Scaffolded inverse blended learning: an approach to teach an online general chemistry course, Journal of Chemical Education 97 (2020) 2839-2844.

DOI: https://doi.org/10.1021/acs.jchemed.0c00436.

[7] D. Blizak, S. Blizak, O. Bouchenak, K. Yahiaoui, Students' perceptions regarding the abrupt transition to online learning during the covid-19 pandemic: case of faculty chemistry and hydrocarbons at the University of BoumerdesAlgeria, Journal of Chemical Education 97 (2020) 2466-2471.

DOI:

https://doi.org/10.1021/acs.jchemed.0c00668.

[8] R. Kalman, M.M. Esparza, C. Weston, Student veiws of the online learning process during the covid-19 pandemic: a comparison of upper-level and entry-level undergraduate perspectives, Journal of Chemical Education 97 (2020) 3353-3357. DOI: https://doi.org/10.1021/acs.jchemed.0c00712.

[9] W. Hulukati, M. Puluhulawa, A.S.D. Manangin, M, M. Rahim, M.R. Djibran, The development of learning motivation video as guidance and counseling media for senior high school (equivalent) students, in: Proceedings of the International Conference on Education, Science and Technology, Journal Physics: Conference Series, vol. 1387, IOP Publishing, Bristol, 2019. DOI: https://doi.org/10.1088/17426596/1387/1/012129

[10] N.P. Brataningrum, L. Saptono, The influence of the effectiveness of accounting learning process on student learning achievements, Cakrawala Pendidikan $36 \quad$ (2017) 342-356. DOI: https://dx.doi.org/10.21831/cp.v36i3.14139.

[11] S. Shin, J. K. Lee, M. Ha, Influence of career motivation on science learning in Korean highschool students, In: EURASIA Journal of Mathematics Science and Technology Education 13 (2017) 1517-1538. DOI: https://doi.org/10.12973/eurasia.2017.00683a. 
[12] P. R. Pintrich, E.V. De Groot, Motivational and self-regulated learning components of classroom academic performance, Journal of Educational $\begin{array}{llll}\text { Psychology } & 82 & \text { (1990) 33-40. DOI: }\end{array}$ https://doi.org/10.1037/0022-0663.82.1.33.

[13] P.R. Pintrich, D.A.F. Smith, T. Garcia, W.J. Mckeachie, Realibility and predictive validity of the motivated strategies for learning questionnaire, in: Educational and Psychological Measurment 53 (1993) 801-813. DOI: https://doi.org/10.1177/0013164493053003024.

[14] M. M. Z. Al-Dien, Student academic freedom in egypt: perceptions of university education students, Universal Journal of Educational Research 4 (2016) 432-4444. DOI: https://dx.doi.org/10.13189/ujer.2016.040218.

[15] P. Mishra, C.M. Pandey, U. Singh, A. Gupta, C. Sahu, A Keshri, Descriptive statistics and normality tests for statistical data, Annals of Cardiac Anaesthesia 22(1) 2019 67-72. DOI: https://doi.org/10.4103/aca.ACA_157_18.

[16] A. Rachmatullah, F. Roshayanti, S. Shin, J.K. Lee, M. Ha, The Secondary-Student Science Learning
Motivation in Korea and Indonesia, in: Eurasia Journal of Mathematics, Science and Technology Education 14 (2018) 3123-314. DOI: https://doi.org/10.29333/ejmste/91665.

[17] K. Salta, D. Koulougliotis, Domain specificity of motivation: chemistry and physics learning among undergraduate students of three academic majors, in: International Journal of Science Education 42 (2020) 253-270. DOI: https://doi.org/10.1080/09500693.2019.1708511

[18] S. Li, A study on the influence of learning motivation on learning engagement of chinese immersion primary school students in the united states, Proceedings of the $3^{\text {rd }}$ International Seminar on Education Research and Social Science (ISERSS), vol. 506, Atlantis Press, Amsterdam, The Netherlands, 2021, pp. 214-219. DOI: https://doi.org/10.2991/assehr.k.210120.041.

[19] M.F. Schumm, F. X. Bogner, Measuring adolescent science motivation, International Journal of Science Education 38 (2018) 434-449. DOI: https://doi.org/10.1080/09500693.2016.1147659. 